\title{
Screening for Salt and Water Stress Tolerance in Fir (Abies alba) Populations
}

\author{
Irina M. TODEA (MORAR) ${ }^{1}$, Sara GONZÁLEZ-ORENGA², Mariola \\ PLAZAS $^{3}$, Adriana F. SESTRAS ${ }^{1 *}$, Jaime PROHENS ${ }^{3}$, Oscar VICENTE ${ }^{3}$, \\ Radu E. SESTRAS ${ }^{1}$, Monica BOSCAIU ${ }^{2}$ \\ ${ }^{1}$ University of Agricultural Sciences and Veterinary Medicine, Faculty of Horticulture, 3-5 Manastur St., 400372 Cluj-Napoca, \\ Romania;irina.todea@usamvcluj.ro; adriana.sestras@usamvcluj.ro ('correspondingauthor);rsestras@usamvcluj.ro \\ ${ }^{2}$ Universitat Politècnica de València, Mediterranean Agroforestry Institute (IAM), Camino de Vera s/n, 46022 Valencia, \\ Spain;sagonor@etsia.upv.es; mobosnea@eaf.upv.es \\ ${ }^{3}$ Universitat Politècnica de Valencia, Institute for the Preservation and Improvement of Valencian Agrodiversity (COMAV), Camino de Vera \\ s/n,46022Valencia,Spain; maplaav@btc.upv.es;jprohens@btc.upv.es; ovicente@upvnet.upv.es
}

\begin{abstract}
Drought periods are becoming more frequent and intense, due to the effects of climate change, threatening natural habitats worldwide, including European forests. Forest trees can also be affected by high soil salinity, because of the common practice of de-icing of mountain roads with $\mathrm{NaCl}$ in winter. We have evaluated the responses to salt and water stress of silver fir (Abies alba), an important forest species for which very limited information is available. One-year-old fir seedlings, with origin in seven different locations in Romania, were subjected to salt (watering with $\mathrm{NaCl}$ solutions of increasing concentrations) and water deficit (complete withholding of irrigation) treatments in the greenhouse. After one month, plant material was harvested and different morphological parameters were determined in the stressed and control plants. Both stress treatments inhibited growth of fir seedlings from all seven provenances, although quantitative differences in the responses to stress were observed between populations. Growth inhibition was established by the relative reduction - as compared to the non-stressed controls - in several parameters, such as stem elongation, root length, number of needles, or fresh weight and water content of roots and needles. Statistical multivariate analysis of the results suggested that seedlings from Valea Morii (population 6) were the most tolerant to both, water deficit and high $(300 \mathrm{mM} \mathrm{NaCl})$ salt concentrations. These results support the possibility to screen a large number of individuals from different populations, at the seedling stage, to select Abies alba genotypes with enhanced drought and/or salinity tolerance.
\end{abstract}

Keywords: climate change; forests; growth parameters; salt stress; stress tolerance; water deficit

\section{Introduction}

Shortly, forest tree species will need to cope with changing environmental conditions due to global warming, which is already threatening their natural habitats (Allen $e t$ al., 2010; Gilliam, 2016). Even though the harmful effects of climate change will be more severe in arid and semiarid regions - for example in the Mediterranean basin - forests in temperate regions, such as Central Europe, will also be affected. Forests represent one of the main components of the biosphere, containing a substantial fraction of the terrestrial biodiversity. They are a central component of Earth's biogeochemical systems and a source of ecosystem services important for human well-being. Forests also have the potential to mitigate the effects of climate change by their capacity to absorb $\mathrm{CO}_{2}$ (Shvidenko et al., 2005; Sturrock et al., 2011).

Comparative analyses of the variability within and between populations of one species, in their responses to environmental stress factors, should provide valuable information on the adaptability of a species as a whole, or of a particular forest ecosystem, to the consequences of climate change (Savolainen et al., 2007). According to the Intergovernmental Panel on Climate Change (IPCC, 
1064

2014), average temperatures could increase by $2-4{ }^{\circ} \mathrm{C}$ in Europe within the next 50 years, which would cause considerable changes in annual and seasonal precipitation patterns and amounts. Climate change will generate additional challenges for the biological diversity of forest ecosystems and forest management practices (Savolainen $e t$ al., 2007).

Transforming forests from the present genotypes, which are not particularly well adapted to the expected climate change conditions, to genotypes that may be more suitable for the foreseeable changing environment, is a way to prevent risks in management processes (Hanewinkel et al., 2009). Therefore, to improve the future of our forests, it is essential to promote research focused on the physiological, biochemical and molecular responses of trees to abiotic stress, together with the implementation of appropriate reforestation techniques.

Global warming brings as a direct effect increased evapotranspiration, generating periods of drought that are becoming longer, more frequent and intense throughout the world (IPCC, 2014). Drought affects plants both at physiological and biochemical levels (Osakabe et al., 2014) and is one of the major stress factors currently threatening global ecosystems (Sandoval et al., 2016).

In addition to drought, salinity is another important environmental stress factor, which contributes to shaping the distribution of plant species in nature. At the same time, salinity is responsible for substantial losses in crop production worldwide. The accumulation of dissolved salts in irrigation water leads to secondary salinization of arable land, especially in arid and semi-arid regions; this problem will worsen soon, mostly due also to the effects of climate change (Fita et al., 2015; Al Hassan et al., 2016). Salinity and drought are amongst the most critical limiting factors in the biological cycle of plants, preventing seed germination, reducing vegetative growth and reproductive success (Şchiop et al., 2015, 2017). They affect many biochemical and physiological parameters of plants (Osakabe et al., 2014), and currently are the most challenging stress factors at the global level (Bartlett et al., 2012; Sandoval et al., 2016).

The genus Abies has a mostly circum-Mediterranean distribution in Europe. Silver fir (Abies alba Mill.) is the only species in this genus with a broad European range, whereas the remaining taxa are mostly allopatric, each with a distribution limited to some specific regions (Schütt, 1991; Dering et al., 2014). Silver fir is one of the most important forest trees in Central Europe, especially in the mountain regions (Dobrowolska, 2008), and in parts of southern and eastern Europe. It is one of the largest species of this genus and, at the same time, one of the most valuable conifers for economic and historical reasons in Europe. Silver fir is often distributed over areas with altitudes of 500-2000 m and requires relatively high humidity conditions throughout the year, with annual average rainfall between 700 and 1800 mm (Tinner et al., 2013).

Silver fir is a fundamental species for maintaining high biodiversity in forested ecosystems due to its adaptability to environmental conditions, shade tolerance and the ability to coexist with many others tree species (Dobrowolska et al.,
2017). It is tolerant to a wide range of soil conditions, nutrient content and $\mathrm{pH}$ levels, but grows optimally on deep soils, rich in nutrients, fine to medium textured and well-drained. Silver fir ecotypes show remarkable variations in features such as frost, shade and drought resistance. Silver fir is generally associated with beech (Fagus sylvatica) in lower and middle mountain belts and with Norway spruce (Picea abies) in the upper mountain belt (Muller et al., 2007), and it is found at the upper tree limit also mixed with Scots pine (Pinus sylvestris). At lower altitudes, it competes with beech, being the first conifer species to appear among them (Ellenberg, 2009).

In Romania, silver fir has a discontinuous distribution. The areas where it is most frequently found are the Eastern Carpathians and the Carpathians of Curvature. Silver fir also appears in the Southern, west of Olt, mixed with spruce and beech and sometimes in the Apuseni Mountains (Stănescu, 1979). This species grows at altitudes between 200-300 $\mathrm{m}$ in Northern Moldova, $400-500 \mathrm{~m}$ in the Eastern Carpathians, and above $1000 \mathrm{~m}$ in the Semenic and the Southern Carpathians. Trees of this species have been located at a minimum altitude of $192 \mathrm{~m}$, in Banat, and at maximum altitudes in the Southern Carpathians, where it reaches up to $1300-1400 \mathrm{~m}$, rarely $1500 \mathrm{~m}$ and only exceptionally, isolated specimens reach up to $1700-1750 \mathrm{~m}$ altitude (Şofletea and Curtu, 2007).

It is forecasted that, in the not-so-distant future, climate change will reduce the abundance and distribution range of silver fir, so that better forest management practices are recommended to improve tree conservation (Dobrowolska et al., 2017). To understand the mechanisms of Abies alba, tolerance to environmental stresses is therefore of fundamental importance. However, there is very limited information on the responses of forest trees, in general, and silver fir, in particular, to abiotic stress, especially to salt stress. Conifers have a relatively high sensitivity to salt and do not grow in natural saline environments (Larcher $e t a l$., 2001), which explains the general lack of interest in studying their possible physiological, biochemical and molecular responses to high salinity. However, coniferous trees are often found on the edges of the roads, especially in mountain areas, where winter activities such as ice-removal on mountain roads using vast amounts of $\mathrm{NaCl}$, threaten their growth. Already in the 1980 s, it was reported that salt applications in winter were causing the death of over 700,000 trees in Western Europe (Fliuckiger and Braun, 1981), and this practice continues despite some efforts made in recent years to find alternatives.

As mentioned above, an appropriate strategy to cope, at least partly, with the deleterious effects of climate change on forest ecosystems, would be to select plant material with enhanced tolerance to abiotic stress, particularly to drought and/or salinity, to be used in reforestation programmers. This requires the screening of different forest species and a large number of genotypes within one species, for their salt and water-stress tolerance. Studies with this aim have already been initiated in forest species, such as Picea abies (Schiop et al., 2015, 2017) or Larix decidua (Plesa et al., 2018, 2019). 
As an initial step to perform similar studies in Abies alba, we have evaluated the growth responses of one-year-old silver fir seedlings subjected to controlled salt and water stress treatments under greenhouse conditions. The seedlings were obtained from seven different locations in the Romanian mountains. The main aim of the work was to try and establish a rank of salt and drought tolerance of the seven populations, based on their relative degree of growth inhibition under stress, since inhibition of growth is the most general effect of stress on plants. In this way, we expected to be able to pre-select some Abies alba genotype(s) with enhanced stress tolerance, to be used in further studies.

\section{Materials and Methods}

\section{Seedlingorigin, growth conditions and stress treatments}

Silver fir (Abies alba Mill.) seedlings of seven populations were obtained from different areas in Romania. The geographic locations of the populations are descripted of each population in Table 1. One-year-old seedlings were transferred to the greenhouse of the Institute for the Preservation and Improvement of Valencian Agrodiversity (COMAV), Polytechnic University of Valencia, Valencia, Spain.

Seedlings were maintained in 0.3-liter individual pots containing Humin-substrat N3 (Klasmann-Deilmann, Germany) substrate, in a greenhouse with controlled temperature (maximum of $30^{\circ} \mathrm{C}$ and minimum of $15^{\circ} \mathrm{C}$ ) under natural light. The pots were kept in plastic trays, 35 pots per tray, watered twice a week with tap water; salt and water stress treatments were started after 21 days of acclimatization. Salt treatments were applied by watering the plants twice weekly (Monday and Thursday) with solutions of final concentrations: 0 (for the controls), 100, 200 and $300 \mathrm{mM} \mathrm{NaCl}$ in tap water, adding $1 \mathrm{~L}$ of solution per tray. The water stress (WS) treatment was performed by withholding irrigation altogether. After 30 days, plant samples (needles, stems and roots) were collected separately for the measurement of a set of growth parameters. Substrate samples were taken from the pots at the same time.

\section{Substrate analysis}

At the end of the treatments, electrical conductivity and humidity were determined in the soil samples. The electrical conductivity (EC) is a parameter related to the concentration of ions in the soil and, therefore, to the degree of salt stress affecting the plants (Bresler et al., 1982). Soil samples were collected from each pot, air dried, and then passed through a 2-millimetre sieve. A soil: water suspension (1:5) was prepared in deionized water, mixed at $600 \mathrm{rpm}$ at $21{ }^{\circ} \mathrm{C}$ for one hour and then filtered through filter paper. Electrical conductivity (EC1:5) was measured with a Crison 522 Conductivity-meter and expressed in $\mathrm{dS} \mathrm{m}-1$. The gravimetric method was used to determine soil moisture as follows: a fraction of each soil sample was weighed (soil weight, SW), dried in an oven at $105^{\circ} \mathrm{C}$ until constant weight and then weighed again (dry soil weight, DSW). The content of soil water was calculated as:

Soil humidity $(\%)=[($ SW $-\mathrm{DSW}) / \mathrm{SW}] \times 100$.

\section{Analysis of plant growth parameters}

Before starting the stress treatments, the stem length and the number of needles were determined for all Abies alba seedlings. To analyse the effects of water stress and salt stress at the stage of early vegetative growth, the following parameters were determined at the end of the treatments, in control and stressed seedlings: increases in stem length (SL) and in the number of needles (Nno) with respect to the values measured at time 0 ; root length (RL), fresh weight (FW) of roots and needles, dry weight (DW) of roots and needles, and water content percentage (WC\%) of roots and needles. To determine the water content percentage, part of the fresh material (roots and needles) was weighed (FW), dried at $65^{\circ} \mathrm{C}$ for $48-72 \mathrm{~h}$, until reaching constant weight, and weighed again (DW). WC\% was calculated by the following formula:

$$
\mathrm{WC} \%=[(\mathrm{FW}-\mathrm{DW}) / \mathrm{FW}] \times 100
$$

\section{Statistical analyses}

Data were analyzed using the programme Statgraphics Centurion XVI (Statgraphics Technologies, The Plains, VA, USA).

Table 1. Location and climatic characteristics of the seven provenances of silver fir seedlings

\begin{tabular}{|c|c|c|c|c|c|c|c|}
\hline $\mathrm{Nr}$ & Population & County & Administrative location & $\begin{array}{l}\text { Latitude/ } \\
\text { Longitude }\end{array}$ & $\begin{array}{c}\text { Mean annual } \\
\text { temperature }\left({ }^{\circ} \mathrm{C}\right)\end{array}$ & $\begin{array}{c}\text { Mean annual } \\
\text { precipitation }(\mathrm{mm})\end{array}$ & $\begin{array}{l}\text { Altitude } \\
\text { (m asl) }\end{array}$ \\
\hline 1. & Valea Bistrei & Alba & $\begin{array}{l}\text { OSP. Abrud, UP III, } \\
\text { u.a. } 228 \mathrm{~B}\end{array}$ & $46^{\circ} 27^{\prime} \mathrm{N} / 23^{\circ} 01^{\prime} \mathrm{E}$ & 5.5 & 922 & $1050-1325$ \\
\hline 2. & $\begin{array}{l}\text { Someșul } \\
\text { Rece }\end{array}$ & Cluj & $\begin{array}{c}\text { OS. Someșul Rece UP I } \\
\text { u.a. 92A }\end{array}$ & $46^{\circ} 38^{\prime} \mathrm{N} / 23^{\circ} 14^{\prime} \mathrm{E}$ & 7.1 & 885 & $690-1250$ \\
\hline 3. & Avrig & Sibiu & $\begin{array}{l}\text { OS Izvorul Florii UP III u.a } \\
75 \mathrm{~A}\end{array}$ & $45^{\circ} 37^{\prime} \mathrm{N} / 24^{\circ} 27^{\prime} \mathrm{E}$ & 5.7 & 798 & $900-1150$ \\
\hline 4. & Budescu & Maramureș & $\begin{array}{c}\text { OS. Poieni, UP IV, } \\
\text { u.a } 96 \text { A }\end{array}$ & $47^{\circ} 54^{\prime} \mathrm{N} / 24^{\circ} 36^{\prime} \mathrm{E}$ & 6.2 & 986 & $860-1120$ \\
\hline 5. & Sohodol & Alba & OSP. Abrud UP IV $18 \mathrm{C}$ & $46^{\circ} 20^{\prime} \mathrm{N} / 23^{\circ} 06^{\prime} \mathrm{E}$ & 5.3 & 794 & $870-1030$ \\
\hline 6. & Valea Morii & Alba & $\begin{array}{l}\text { OSP. Abrud U V, } \\
\text { u.a } 39\end{array}$ & $46^{\circ} 19^{\prime} \mathrm{N} / 22^{\circ} 56^{\prime} \mathrm{E}$ & 5.1 & 850 & $1080-982$ \\
\hline 7. & Gârda Seacă & Alba & $\begin{array}{c}\text { OS. Gârda UP VI, } \\
\text { u.a } 20 \mathrm{H}\end{array}$ & $46^{\circ} 31^{\prime} \mathrm{N} / 22^{\circ} 46^{\prime} \mathrm{E}$ & 4.9 & 822 & $1090-1285$ \\
\hline
\end{tabular}

IPopulation description according to the National Catalogue of Forest Reproductive Materials, Bucharest (Pârnuță et al., 2012) 
Before the analysis of variance, the Shapiro-Wilk test was used to check for the validity of normality assumption and Levene's test to test the homogeneity of variance. If ANOVA requirements were met, significant differences among treatments were tested by one-way ANOVA at the 95\% confidence level, and post hoc comparisons were made using the Tukey HSD test. All mean values throughout the text are followed by their $\mathrm{SE}$ and based on five biological replicas.

A Principal Component Analysis (PCA) was performed using the mean values of each morphological trait analyzed for the seven populations.

\section{Results}

\section{Substrate analysis}

As it should be expected, the electrical conductivity (EC1:5) of the pot substrates increased after four weeks of salt treatment, in parallel to increasing $\mathrm{NaCl}$ concentration in the irrigation solutions, for all seven tested populations of Abies alba. The mean substrate EC1:5 in the presence of $300 \mathrm{mM} \mathrm{NaCl}\left(20 \mathrm{dS} \mathrm{m}^{-1}\right)$ was about 10-fold higher than that registered in the substrate of control plants, for all populations (Fig. 1a). The substrates of water-stressed plants also showed significantly increased EC1:5, as compared to the controls, between 2- and 3-fold for the different fir populations (Fig. 1b). This result can be explained by the concentration of ions present in the pot substrates at the beginning of the water deficit treatment, due to evaporation and water uptake by the plants.

On the other hand, differences in soil moisture between the pots of seedlings from the seven populations were small and, in most cases, non-significant statistically. We observed a slight decrease of soil humidity with increasing external salt concentrations but, here again, the differences were significant only for some of the provenances, namely, populations 1 (Valea Bistrei), 2 (Somessul Rece) and 7 (Gârda Seacă) (Fig. 1c). Regarding the water stress treatments, soil humidity decreased significantly in the pots of all plants, as expected, although with clear quantitative differences between populations. The most substantial reduction of substrate moisture was observed in pots of seedlings from population 1 (Valea Bistrei), about 7 -fold less than in the corresponding control. The smallest differences were detected for population 3 (Avrig), closely followed by populations 4 and 5 (Budescu and Sohodol, respectively) (Fig. 1d).

\section{Plant growth analysis}

Salt stress appeared to inhibit the growth of Abies alba seedlings, as shown, for example, by the relative reduction in the average increment of stem length in all stressed plants, compared to the corresponding controls grown under normal conditions; however, in several populations [Avrig (3), Budescu (4) and Valea Morii (6)], the differences were not significant (Fig. 2a). Using the same parameter, the elongation of the stems of the stressed plants in comparison to that of the controls, slower growth was also detected, in general, in water-stressed plants, with similar patterns to those observed in salt-stressed plants (Fig. 2b). It should be mentioned that significant differences in stem elongation have been observed between populations in the control plants, indicating different growth rates and that plants growing relatively slower, such as those from population 4 (Budescu), also showed a relatively weaker stress-induced inhibition of growth.

Salt stress and water deficit decreased root length in Abies alba seedlings, with respect to the non-stressed controls (Fig. 3a, b); the observed differences were statistically significant for both stress conditions and all provenances, except for the water stress treatments in populations 3 (Avrig) and 5 (Sohodol) (Fig. 3b).

Stress-induced growth inhibition was also reflected in a general reduction of the root fresh weight, at least at the higher $\mathrm{NaCl}$ concentrations tested $(200$ and $300 \mathrm{mM})$, in relation to that of the corresponding controls (Fig. 3c). Relative root fresh weight also decreased in response to water stress, in general with even more significant differences with the controls than those observed in the salt treatments, except for population 1 (Valea Bistrei) (Fig. 3d). Differences in root FW between populations were observed in the control seedlings, with those from Somesul Rece (2), Sohodol (5) and Gârda Seacă (7) showing significantly higher values than the other four provenances (Fig. $3 c, d$ ).

Increasing $\mathrm{NaCl}$ concentrations in the watering solutions generally caused significant dehydration of the silver fir roots, for most populations (Fig. 3e). The same effect was observed in the roots of the seedlings that underwent the water deficit treatment, especially on those from Valea Bistrei, Valea Morii and Gârda Seacă (Fig. 3f).

Apparent quantitative differences between provenances were observed regarding the increment in the number of needles in control seedlings during the 30 days of treatment, with population 1 (Valea Bistrei) showing the highest average value $(\sim 5)$; according to this criterion, the slowest growth was detected in population 4 (Budescu), closely followed by 6 (Valea Morii) and 7 (Gârda Seacă) (Fig. 4a, b). As a general trend, the relative increase in the number of needles decreased significantly in the presence of salt (Fig. 4a), as well as in water-stressed seedlings (Fig. 4b), except for populations 6 and 7. Seedlings originated in Budescu were the most affected by both types of stress, with no new needles formed during the stress treatments.

Salt-induced changes in the fresh weight of the needles showed a more regular pattern, with some quantitative differences between populations but a general, concentration-dependent FW decrease for all of them (Fig. 4c). Water deficit affected needle FW to a much lesser extent than salt stress under our experimental conditions; small differences with the non-stressed controls were generally observed, which were statistically significant only in seedlings from the Sohodol (5) and Gârda Seacă (7) populations (Fig. 4d).

The observed $\mathrm{NaCl}$-induced decrease in needle $\mathrm{FW}$ was partly due to dehydration of the needles in the presence of salt, as a significant, concentration-dependent reduction of WC\% was observed in all populations (Fig. 4e). Here again, there were quantitative differences between populations, with the highest resistance to dehydration detected in seedlings from Avrig (3), whereas those from Budescu (4) showed the lowest WC, below 50\%, in the presence of 200 or $300 \mathrm{mM} \mathrm{NaCl}$ (Fig. 4e). Water stress also caused a significant reduction of needle WC in seedlings from all 
population, except Valea Morii (6) (Fig. 4f). However, similarly to the observed changes in needle FW, 30 days of water deficit generally affected needle dehydration less than watering the plants for the same period with high (200-300 $\mathrm{mM} \mathrm{NaCl}$ ) salt concentrations, as shown by the relatively small differences in WC\% between water-stressed and control plants (Fig. 4f).

Statistics analysis of data

Two-way ANOVAs were performed considering the effect of salinity and water deficit separately. For salt stress, the effects of the variables 'treatment' and 'population', as well as their interaction, 'treatment' $\times$ 'population', on all measured parameters, in comparison with the controls, are shown in Table 2. All analysed parameters showed a significant variation according to 'treatment'. According to the 'population' variable, except for the increments in stem length and number of leaves, all other parameters showed significant differences between populations. The effect of the interaction of the two variables was significant for the increments in stem length and number of needles, root length, fresh weight of needles, and especially for needle water content.

The results of the two-way ANOVA corresponding to the water stress treatments, in comparison with the controls, are shown in Table 3. In this case, the effect of 'treatment' (A) was significant for all measured parameters except for the increase in the number of needles, whereas that of 'populations' (B) was significant for the fresh weight and water content of needles and roots; their interaction (A $\times B$ ) was not significant for root length and the fresh weight of roots and needles the increment of stem length, and water content in needles.

A multivariate analysis, considering salt stress and water deficit simultaneously, was carried out through a Principal Component Analysis (PCA). The PCA detected three main components with an Eigenvalue $>1$, explaining $82.24 \%$ of the total variability.

In the bi-dimensional graphic presented below (Fig. 5), the first component, explaining $36.61 \%$ of the total variability, is mostly correlated, positively, with variables related to the aerial part of the seedlings, such as the increases in stem length (SL) and number of needles (Nno), or the fresh weight of needles (NFW), but also with the fresh weight of roots (RFW). The second component, which explains an additional $28.07 \%$ of the variability, is more related to the water content of needles (NWC) and roots (RWC).

The PCA allowed discriminating between the different treatments. Mean values in control seedlings fall in the right part of the graph (marked by higher values of needle fresh weight, and increments in stem length and number of needles). Seedlings from the water stress treatment are distributed in the upper part of the figure, as their main trait is the reduction in the water content of roots and needles, whereas those from the salt treatments are forming a separate group. Growth parameters of the different populations (genotypes) are more separated in control and water stress treatments, but grouped more homogenously under salt stress conditions, especially in the presence of 300 $\mathrm{mM} \mathrm{NaCl}$ (Fig. 5).

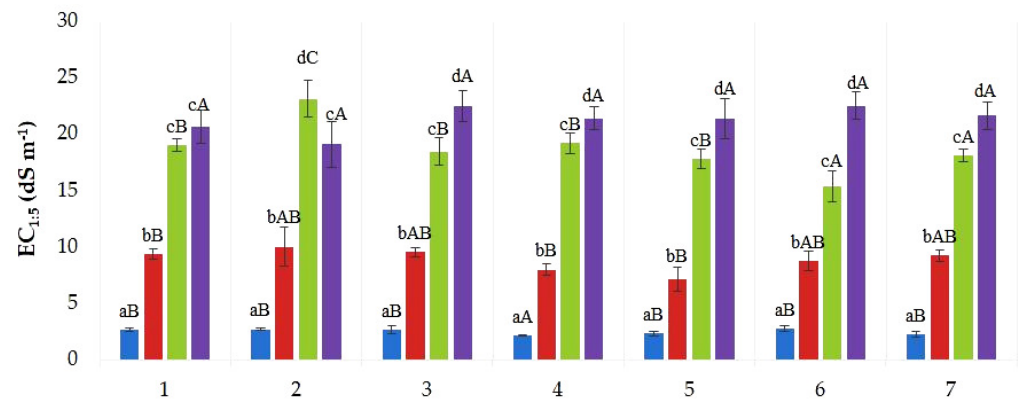

(a)

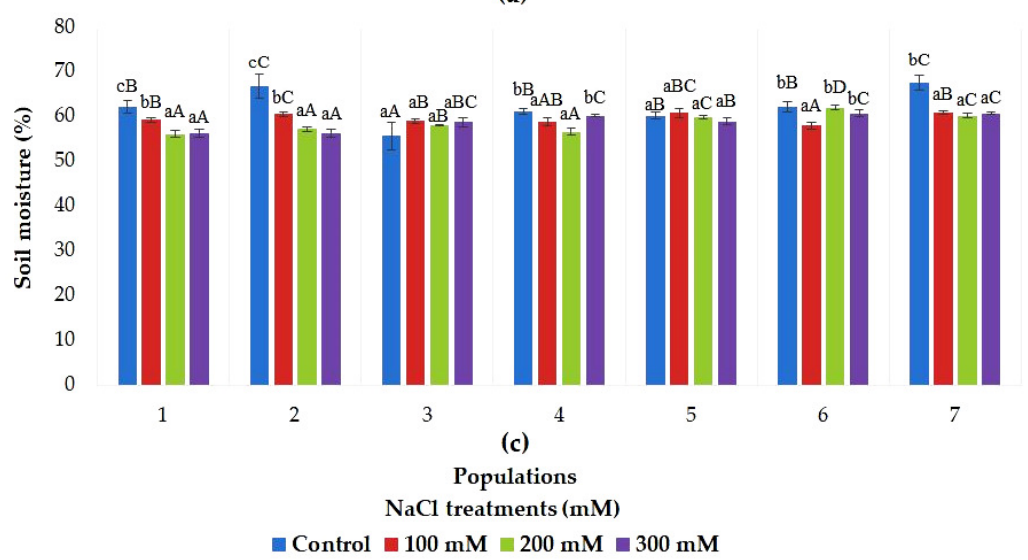

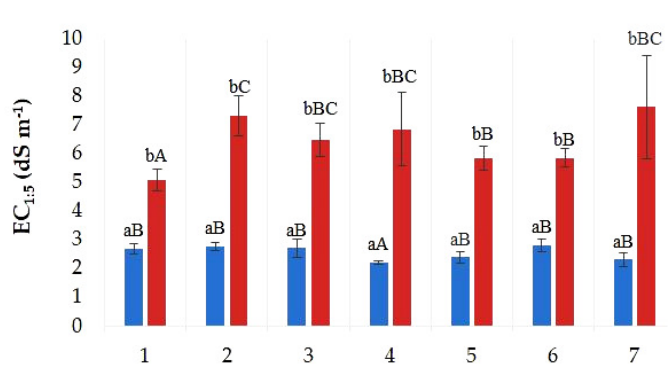

(b)

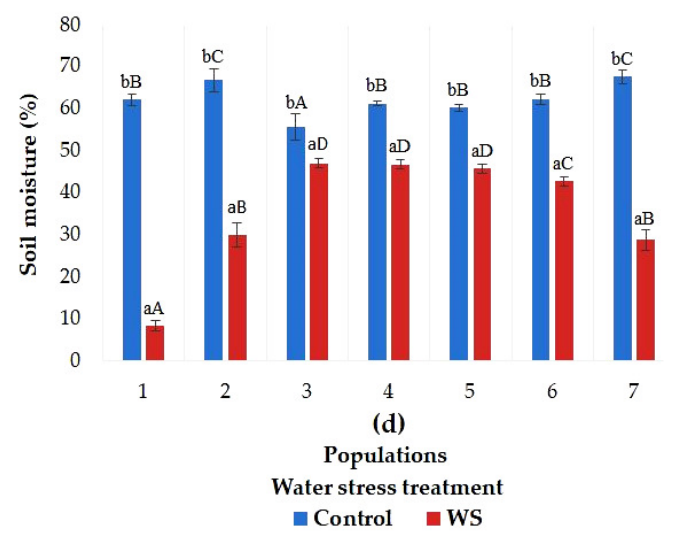

Fig. 1. Substrate electrical conductivity $\left(\mathrm{EC}_{1: 5}\right)(\mathrm{a}, \mathrm{b})$, and soil moisture (\%) (c, d), in the controls and after 30 days of salt stress $(100,200,300 \mathrm{mM} \mathrm{NaCl}$, as indicated) (a, c) or water deficit stress (WS) (b, d). Values shown are means \pm SE $(\mathrm{n}=5)$. Different lowercase letters above the bars indicate significant differences between treatments for each population, and different capital letters indicate significant differences between populations for plants undergoing the same treatment, according to the Tukey test $(\alpha=0.05)$. Population numbers as defined in Table 1 
1068

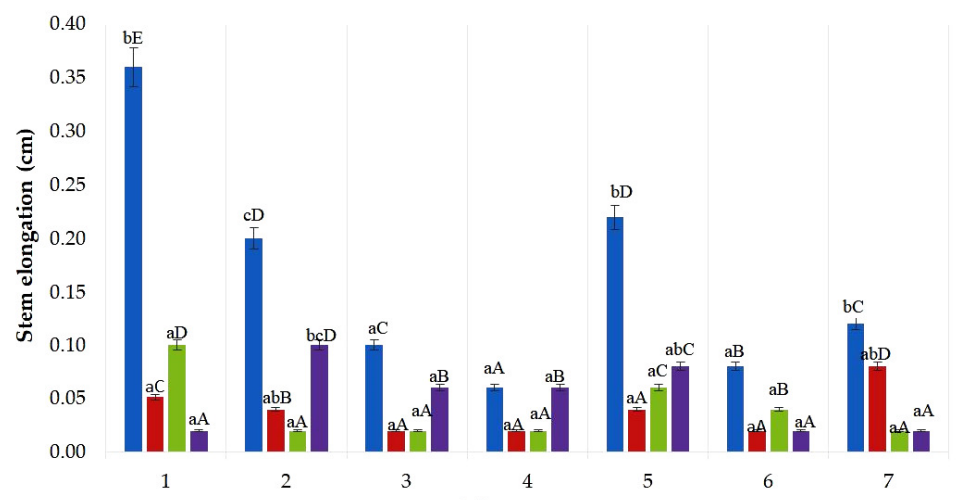

(a)

\section{Populations}

$\mathrm{NaCl}$ treatments (mM)

n Control

$\square 100 \mathrm{mM} \square 200 \mathrm{mM} \square 300 \mathrm{mM}$

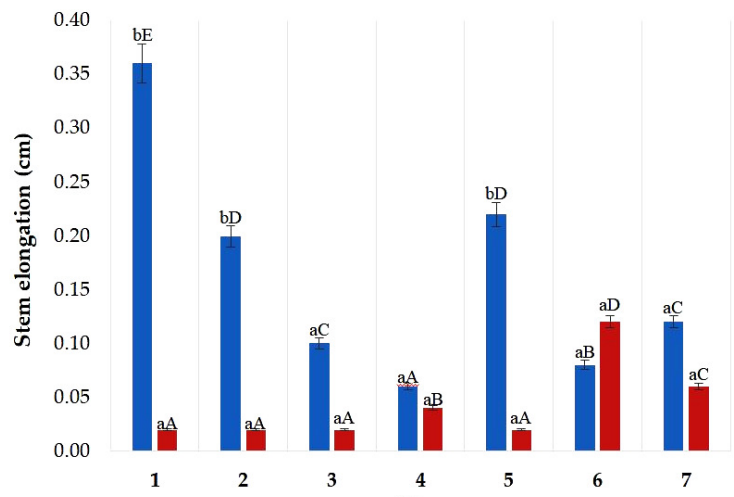

(b)

Populations

Water stress treatment

n Control aWS

Fig. 2. Effect of 30 days of salt stress (a) and water stress (b) treatments on stem elongation in Abies alba. Stem elongation measurements were taken just before starting the treatments (time 0 ), and before collecting the samples (time 30). Values shown are means \pm SE $(n=5)$. Different lowercase letters above the bars indicate significant differences between treatments for each population, and different capital letters indicate significant differences between populations for plants undergoing the same treatment, according to the Tukey test $(\alpha=0.05)$. Population numbers as defined in Table 1
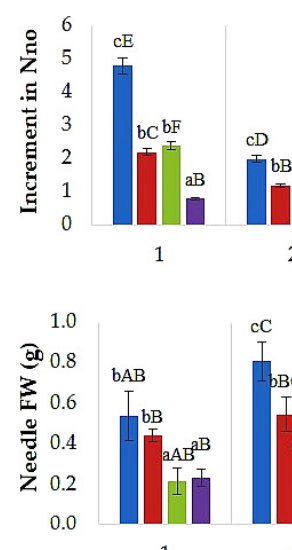

1

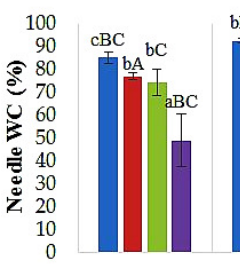

1

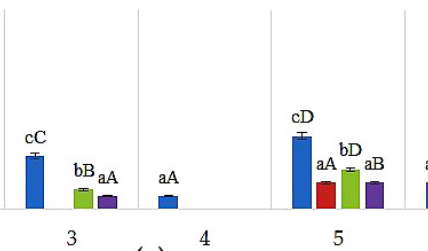

(a)

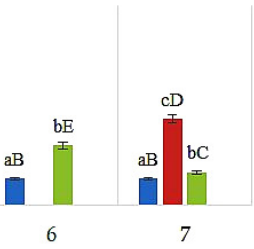

7

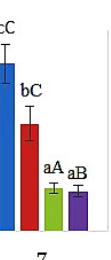

7

(c)

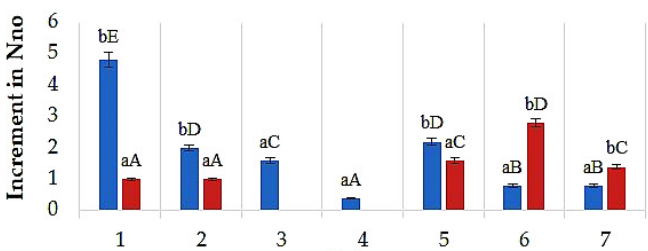

(b)

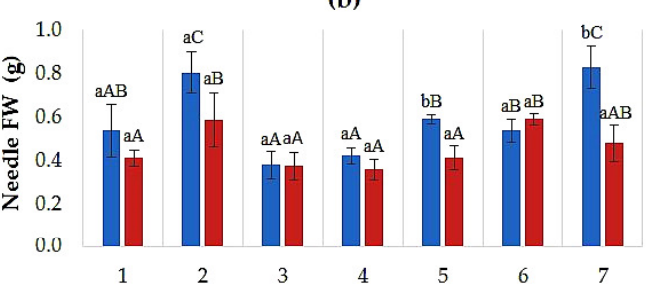

(d)

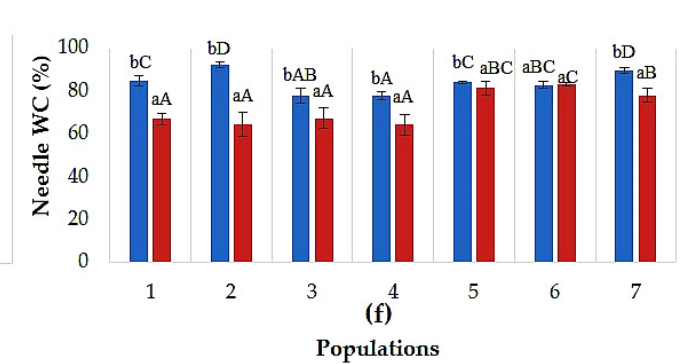

Populations

Water stress treatment

Control

$\square$ Control $\square 100 \mathrm{~mm} \quad \square 200 \mathrm{~mm} \quad \square 300 \mathrm{~mm}$

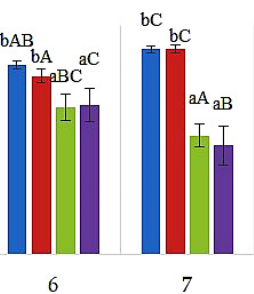

Fig. 3. Increment in the number of needles (Nno) (a, b); needle fresh weight (NFW) (c, d); needle water content (\%) (e, f) for seedlings of Abies alba after 30 days of growth in the presence of the indicated salt concentrations (a, c, e) or subjected to the water deficit treatment $(b, d, f)$. Values shown are means $\pm S E(n=5)$. Different lowercase letters above the bars indicate significant differences between treatments for each population, and different capital letters indicate significant differences between populations for plants undergoing the same treatment, according to the Tukey test $(\alpha=0.05)$. Population numbers as defined in Table 1 

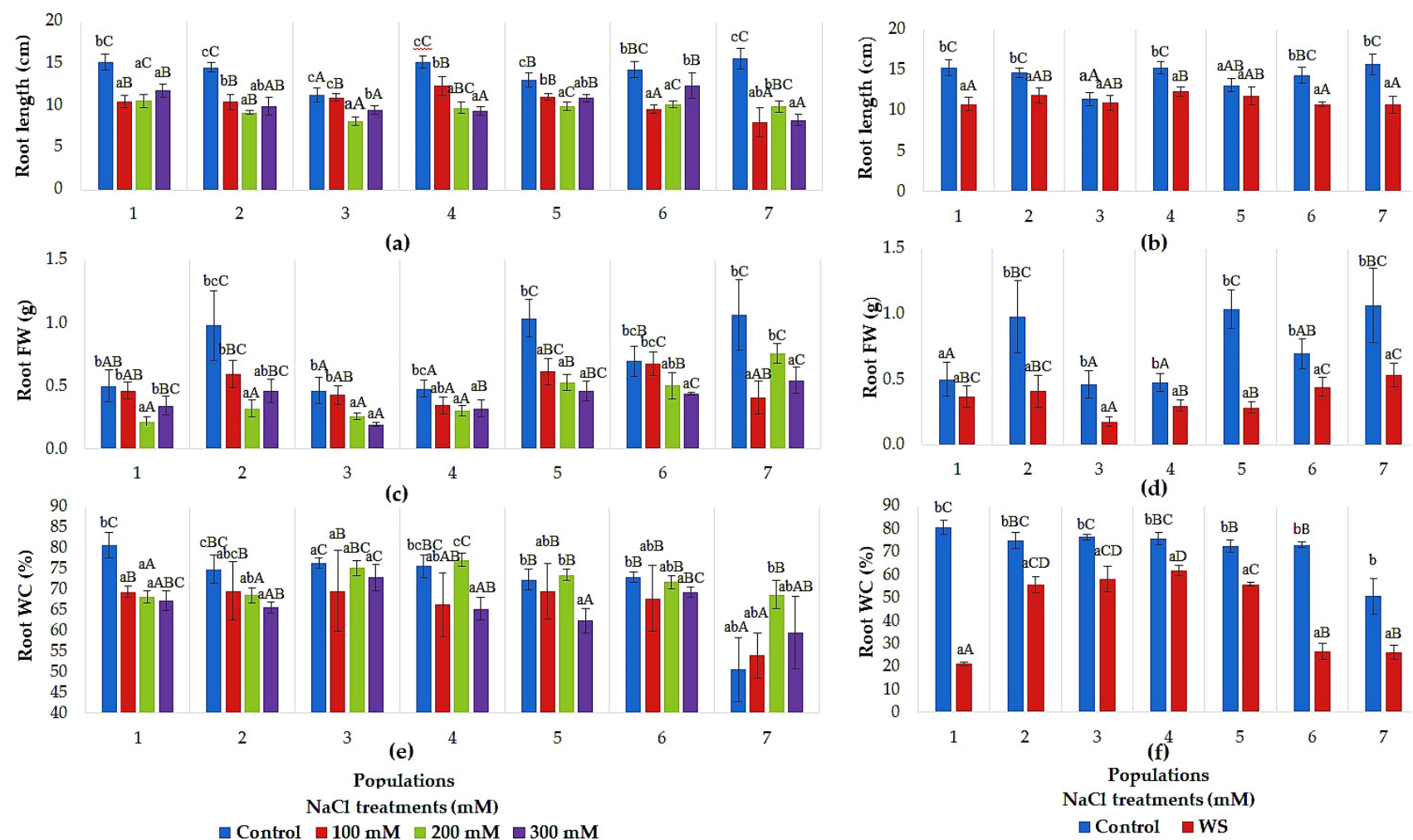

Fig. 4. Root length (a, b); root fresh weight (RFW) (c, d); root water content (RWC) (e, f) for seedlings of Abies alba after 30 days of growth in the presence of the indicated salt concentrations (a, c, e) or subjected to the water deficit treatment (b, d, f). Values shown are means $\pm S E(n=5)$. Different lowercase letters above the bars indicate significant differences between treatments for each population, and different capital letters indicate significant differences between populations for plants undergoing the same treatment, according to the Tukey test $(\alpha=0.05)$. Population numbers as defined in Table 1

\section{Discussion}

Drought and soil salinity both cause osmotic stress in plants, due to a reduction of the water potential at the root level, either because of limited water supply or because the presence of high ion concentrations in the soil; this explains why the initial responses of plants to both types of environmental stress are almost identical (Munns, 2002; Lisar et al., 2012). However, salt stress has a second, specific component, that of ion toxicity, also with deleterious - but somewhat delayed - effects on the plants (Munns and Tester, 2008). Drought and salinity are the most relevant environmental factors responsible for the reduction of crop yields and limiting the distribution of wild species in nature (Boyer, 1982; Zhu, 2001; Fita et al., 2015). Quantitatively, and at the global level, drought is more harmful than salinity, as it is a frequent and widespread natural disaster that has increased significantly in recent decades causing considerable damage worldwide (Boyer, 1982; Osakabe et al., 2014).

The most general and quickest effect of salt stress and water deficit - as well as other stresses - on plants is the reduction or even the complete inhibition of growth. Plants must activate specific stress defense mechanisms, including the synthesis of secondary metabolites and protective proteins, to which they redirect resources such as metabolic precursors and energy, used under normal conditions for primary metabolism, biomass accumulation and, therefore, growth (Zhu, 2001; Munns and Tester, 2008; Gupta and Huang, 2014). Growth inhibition has been observed in practically all studies investigating the effects of drought or salinity on plants (Hand et al., 2017). Therefore, the most convenient and straightforward approach to quantitatively evaluate the effect of abiotic stresses on plants, including water deficit or high soil salinity, is the measurement of some relevant morphological parameters allowing to estimate the degree of stress-induced growth inhibition. When applied in comparative studies to different taxa or populations of a given species, this strategy should permit ranking the studied genotypes according to their relative degree of stress tolerance.

Although there are not many data published on Abies alba, some previous work in the Apuseni Mountains, in Romania, concluded that the radial growth of silver fir is positively correlated with high spring and summer precipitation and mild winters (Kern and Popa, 2007), results which supported a similar study in France (Desplanque et al., 1998). These data indicate that rainfall plays an important role in silver fir distribution and suggest that the species is drought-sensitive, requiring high humidity of air and soil. Regarding responses of Abies alba to salinity, to our knowledge, there are no reports published on this species and few on other species of the genus.

In the case of conifers, being species with slow growth, long-term treatments are generally required to detect the 
1070

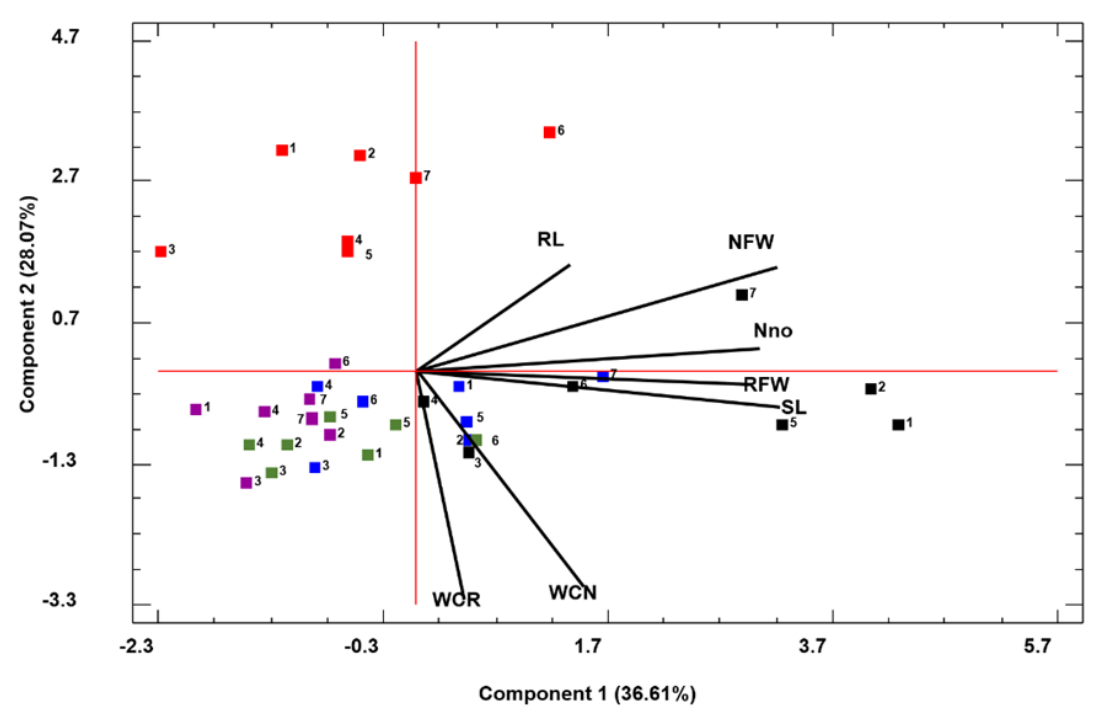

Fig. 5. Principal Component Analysis (PCA) based on the first and second components, which account for $36.61 \%$ and $28.07 \%$, respectively, of the total variability observed in seven Romanian provenances of Abies alba subjected to one-month water or salt stress treatments. Control (black squares), water stress (red squares), $100 \mathrm{mM} \mathrm{NaCl}$ (blue squares), $200 \mathrm{mM} \mathrm{NaCl}$ (green squares), and $300 \mathrm{mM} \mathrm{NaCl}$ (violet squares). SL: increment of stem length, Nno: increment in the number of needles; NFW: needle fresh weight; RFW: root fresh weight; RL: root length; RWC: root water content; NWC: needle water content

Table 2. Two-way ANOVA considering the effect of salt stress treatment $(\mathrm{A})$, population $(\mathrm{B})$ and their interaction $(\mathrm{A} \times \mathrm{B})$ on the morphological parameters analysed

\begin{tabular}{cccc}
\hline Parameter & A- Treatment & B-Treatment & A B - Interaction \\
\hline SL & $0.0151^{*}$ & $0.3184^{\text {ns }}$ & $0.0103^{*}$ \\
RL & $0.0000^{* * *}$ & $0.1569^{\text {ns }}$ & $0.0234^{*}$ \\
Nno & $0.0046^{*}$ & $0.0000^{* * *}$ & $0.049^{* *}$ \\
NFW & $0.0000^{* * *}$ & $0.0000^{* * *}$ & $0.0133^{*}$ \\
RFW & $0.0000^{* * *}$ & $0.0000^{* * *}$ & $0.1615^{\text {ns }}$ \\
NWC & $0.0000^{* * *}$ & $0.0000^{* * *}$ & $0.0000^{* * *}$ \\
RWC & $0.0117^{*}$ & $0.2231^{\text {ns }}$ & \\
\hline
\end{tabular}

Values represent $\mathrm{p}$ and its statistical significance. SL: increment of stem length, RL: root length; Nno: increase in the number of needles; NFW: needle fresh weight; RFW: root fresh weight; NWC: needle water content; RWC: root water content, as indicated. $n s,{ }^{*},{ }^{* *},{ }^{* * *}$ indicate non-significant or significant at $\mathrm{p}<0.05$, $\mathrm{p}<0.01$ or $\mathrm{p}$ $<0.001$, respectively.

Table 3. Two-way ANOVA considering the effect of water stress treatment $(\mathrm{A})$, population $(\mathrm{B})$ and their interaction $(\mathrm{A} \times \mathrm{B})$ on the morphological parameters analyzed

\begin{tabular}{|c|c|c|c|}
\hline Parameter & A-Treatment & B-Treatment & $\mathrm{A} \times \mathrm{B}$ - Interaction \\
\hline SL & $0.0004^{* * *}$ & $0.0999^{\text {ns }}$ & $0.0025^{* *}$ \\
\hline RL & $0.0000^{* * *}$ & $0.0994^{\mathrm{ns}}$ & $0.1357^{\mathrm{ns}}$ \\
\hline Nno & $0.1110^{\mathrm{ns}}$ & $0.3650^{\mathrm{ns}}$ & $0.0254^{*}$ \\
\hline NFW & $0.0020^{*}$ & $0.0001^{* * *}$ & $0.1320^{\text {ns }}$ \\
\hline RFW & $0.0000^{* * *}$ & $0.0071^{* *}$ & $0.2121^{\mathrm{ns}}$ \\
\hline NWC & $0.0000^{* * *}$ & $0.0000^{* * *}$ & $0.0000^{* * *}$ \\
\hline RWC & $0.0000^{* * *}$ & $0.0000^{* * *}$ & $0.0000^{* * *}$ \\
\hline
\end{tabular}

Values represent $\mathrm{p}$ and its statistical significance. SL: increment of stem length, RL: root length; Nno: increase in the number of needles; NFW: needle fresh weight; RFW: root fresh weight; NWC: needle water content; RWC: root water content, as indicated. $n s,{ }^{*},{ }^{* *},{ }^{* * *}$ indicate non-significant or significant at $\mathrm{p}<0.05$, $\mathrm{p}<0.01$ or $\mathrm{p}$ $<0.001$, respectively.

effects of the applied stress (Șchiop et al., 2015). Although the silver fir is considered a slow-growing species, especially in the first years of life (Wolf, 2003), in our experiments, one-month treatments of one-year-old seedlings were sufficient to detect significant relative reductions in some growth parameters, such as stem length, root length, or the number of needles, compared to the unstressed controls. A significant reduction of needle fresh weight in response to increasing salt concentrations or the water stress treatments was also observed, partly due to the stress-induced dehydration of the needles, detected for all populations.
In our experimental conditions, therefore, silver fir does not seem to be very resistant to water deficit at the seedling stage (in agreement with the published data on adult trees mentioned above) or too high salt concentrations, as the stress treatments clearly inhibited seedling growth. It is important to mention that significant differences in the growth inhibition patterns were observed between the investigated populations, which coincide with previous studies suggesting that there is a high differentiation in silver fir populations regarding growth, ecophysiological and biochemical traits, caused by disjunctions in its distribution 
areas (Konnert and Bergmann, 1995; Feurdean and Willis, 2008). The multivariate statistical analysis of our experimental data confirmed this notion, indicating that not only the effect of the treatment was significant, but also that of the 'population' variable and, for some parameters, also their interactions. Therefore, the responses to stress varied according to the geographic origin (genotype) of the seedlings. The observed changes in the different growth parameters, in response to the applied stress treatments, did not show a clear, common pattern allowing to directly establishing a ranking of salt and water stress tolerance of the seven analyzed populations. However, the factorial ANOVA data suggested that fresh weight and water content of needles and roots were the most relevant morphological traits to be considered when assessing the effects of the stress treatments and fir genotypes.

On the other hand, the PCA showed a clear separation of the responses of seedlings from the different populations, in the control and water stress treatments. This indicates differences in the growth rates of the seedlings from different provenances when irrigated regularly, and that the different genotypes do not respond in the same way to drought conditions. Population 6 from Valea Morii appeared to show the best performance under water stress, when comparing the fresh weight and water content of its needles with the corresponding controls. However, the apparently higher drought tolerance of this population should be regarded with caution, as these seedlings had a slow growth rate in the control treatment; likely, the effects of water stress largely depend on the size of the seedlings, smaller plants showing a smaller (relative) reduction of growth. Similarly, according to the PCA, population 7 (Gârda Seacă) was the most tolerant to mild saline stress $(100 \mathrm{mM} \mathrm{NaCl})$. For the treatments with 200 and $300 \mathrm{mM}$ $\mathrm{NaCl}$, projected distances between populations were smaller and they were not so separated, indicating a more homogenous response of fir seedlings to high salinity than to drought. Under these conditions, seedlings from Valea Morii (population 6) were identified as the most salttolerant, as for water stress, which seems logical considering the overlap between the plant responses to both stresses.

\section{Conclusions}

This study provides new experimental data on the responses to drought and salinity of silver fir (Abies alba), for which very little information is available, using one-yearold seedlings collected from seven different locations in Romania. One-month salt and water stress treatments under controlled greenhouse conditions inhibited the growth of seedlings from all provenances, as indicated by the relative reduction - as compared to the non-stressed controls - of several morphological parameters, such as stem elongation, root length, number of needles, or fresh weight and water content of roots and needles. However, quantitative differences in the responses to stress were observed between populations. Statistical multivariate analysis of the results suggested that seedlings from Valea Morii (population 6) were the most tolerant to both, water deficit and high $(300 \mathrm{mM} \mathrm{NaCl})$ salt concentrations. This work represents an initial step to investigate the mechanisms of silver fir tolerance to abiotic stress, and the results reported here should be confirmed in further experiments applying longer stress treatments. Nevertheless, it opens the possibility to select Abies alba genotypes with enhanced drought and/or salinity tolerance, by the screening of a large number of individuals from different populations, at the seedling stage. This approach can be useful for the future management of fir forests and reforestation programmes, in a climate change scenario that is already affecting the natural habitats of this important conifer species.

\section{Acknowledgements}

I.M.T.(M.) was recipients of Erasmus Mundus predoctoral scholarships in UPV financed by the European Commission.

\section{Conflict of Interest}

The authors declare that there are no conflicts of interest related to this article.

\section{References}

Al Hassan M, López Gresa MP, Boscaiu Neagu MT, Vicente Meana Ó (2016). Stress tolerance mechanisms in Juncus: responses to salinity and drought in three Juncus species adapted to different natural environments. Functional Plant Biology 43:949-960.

Bartlett MK, Scoffoni C, Sack L (2012). The determinants of leaf turgor loss point and prediction of drought tolerance of species and biomes: a global meta-analysis. Ecology Letters 15:393-405.

Boyer JS (1982). Plant productivity and environment. Science 218(4571):443-448.

Bresler E, Mcneal BL, Carter DL (1982). Saline and sodic soils. Principles Dynamics - Modeling. Springer - Verlag, Berlin.

Craig DA, Alison KM, Haroun C, Dominique B, Mcdowelle N, Vennetier M, ... Cobb N (2010). A gobal overview of drought and heat-induced tree mortality reveals emerging climate change risks for forests. Forest Ecology and Management 259(45):660-684.

Dering M, Kiewicz K, Boratynska K, Litkowiec M, Iszkuło G, Romo A, Boratynski A (2014). Genetic diversity and inter-specific relations of western Mediterranean relic Abies taxa as compared to the Iberian Abies alba. Flora - Morphology, Distribution, Functional Ecology of Plants 209(7):367-374.

Desplanque C, Rolland C, Michalet R (1998). Dendroécologie comparée du sapin blanc (Abies alba) et de l'épicéa commun (Picea abies) dans une vallée alpine de France. Canadian Journal of Forest Research 28:737748.

Dobrowolska D (2008). Growth and development of silver fir (Abies alba Mill.) regeneration and restoration of the species in the Karkonosze Mountains. Journal of Forest Science 54(9):398-408.

Dobrowolska D, Bončina A, Klumpp R (2017). Ecology and silviculture of silver fir (Abies alba Mill.): a review. Journal of Forest Research 22(6):326-335.

Ellenberg HH (2009). Vegetation ecology of central Europe. Cambridge University Press, 4 th Edition. 
1072

Feurdean A, Willis KJ (2008). Long-term variability of Abies alba in NW Romania: implications for its conservation management. Diversity and Distributions 14(6):1004-1017.

Fita A, Rodríguez-Burruezo A, Boscaiu M, Prohens J, Vicente O (2015). Breeding and domesticating crops adapted to drought and salinity: a new paradigm for increasing food production. Frontiers in Plant Science 6(978).

Flückiger W, Braun S (1981). Perspectives of reducing the deleterious effect ofde-icing salt upon vegetation. Plant and Soil 63(3):527-529.

Gilliam FS (2016). Forest ecosystems of temperate climatic regions: from ancient use to climate change. New Phytologist 212:871-887.

Gupta B, Huang B (2014). Mechanism of salinity tolerance in plants: physiological, biochemical, and molecular characterization. International Journal of Genomics 701596.

Hand M, Taffouo V, Nouck A, Nyemene K, Tonfack B, Meguekam T, Youmbi E (2017). Effects of salt stress on plant growth, nutrient partitioning, chlorophyll content, leaf relative water content, accumulation of osmolytes and antioxidant compounds in pepper (Capsicum annuum L.) cultivars. Notulae Botanicae Horti AgrobotaniciCluj-Napoca 45(2):481-490.

Hanewinkel M, Hummel S, Cullmann DA (2010). Modelling and economic evaluation of forest biome shifts under climate change in Southwest Germany. Forest Ecology and Management 259(4):710719.

IPCC (2014). Intergovernmental panel on climate change. In: Proceedings of the 5th assessment report, WGII, Climate Change. Impacts, adaptation, and vulnerability. Retrieved 2018 September 19 http://www.ipcc.ch/report/ar5/wg2/.

Kern Z, Popa I (2007). Climate-growth relationship of tree species from a mixed stand of Apuseni Mts., Romania. Dendrochronologia 24:109115.

Konnert M, Bergmann F (1995). The geographical distribution of genetic variation of silver fir (Abies alba, Pinaceae) in relation to its migration history. Plant Systematics and Evolution 196:19-30.

Kotuby-Amacher J, Koenig R, Kitchen B (2000). Salinity and plant tolerance. Publication AG-SO-03: Utah State University Extension, Logan.

Larcher W (2001). Physiological plant ecology: ecophysiology and stress physiology of functional groups. Springer-Verlag Berlin Heidelberg New York.

Lisar SYS, Motafakkerazad R, Hossain MM, Rahman IMM (2012). Water stress in plants: Causes, effects and responses. https:/www.intechopen.com/books/water-stress/water-stress-inplants-causes-effects-and-responses.

Muller SD, Nakagawa T, De Beaulieu JL, Court-Picon M, Carcaillet C, Miramont Roiron P, ... Bruneton H (2007). Post-glacial migration of silver fir (Abies alba Mill.) in the south-western Alps.Journal of Biogeography 34(5):876-899.

Munns R(2002). Comparative physiology of salt and water stress. Plant Cell Environment 28:239-250.

Munns R, Tester M (2008). Mechanisms of salinity tolerance. Annual Review in Plant Biology 59:651-681.
Osakabe Y, Osakabe K, Shinozaki K, Tran LSP (2014). Response of plants to water stress. Frontiers in Plant Science 5:86.

Pârnuță G, Stuparu E, Budeanu M, Scărlătescu V, Marica FM, Lalu I,... Curtu AL (2011). Catalogul naţional al resurselor genetice forestiere [National Catalogue of Forest Genetic Resources] (in Romanian). EdituraSilvică, Bucureşti.

Plesa I, Al Hassan M, Sestras AF, Vicente O, Boscaiu M, Sestras RE (2018). Biochemical markers of salt stress in European larch (Larix decidua). Notulae Scientia Biologicae 10(3):430-438.

Plesa IM, González-Orenga S, Al Hassan M, Sestras AF, Vicente O, Prohens J, ... Boscaiu M (2018). Effects of drought and salinity on European larch (Larix decidua Mill.) seedlings. Forests 9(6):320.

Sandoval JF, Yoo CY, Gosney MJ, Mickelbart MV (2016). Growth of Arabidopsis thaliana and Eutrema salsugineum in a closed growing system designed for quantification of plant water use. Journal of Plant Physiology 193:110-118.

Savolainen O, Bokma F, Knürr T, Kärkkäinen K, Pyhäjärvi T, Wachowiak W (2007). Adaptation of forest trees to climate change. In: Proceedings of the climate change and forest genetic diversity: implications for sustainable forest management in Europe. Paris, France, 15-16 March 2006; Biodiversity International: Rome, Italy pp 19.

Schiop ST, Al Hassan M, Sestras AF, Boscaiu M, Sestras RE, Vicente O (2017). Biochemical responses to drought, at the seedling stage, of several Romanian Carpathian populations of Norway spruce (Picea abies L. Karst). Trees 31:1479-1490.

Şchiop TS, Al Hassan M, Sestras AF, Boscaiu M, Sestras R, Vicente O (2015). Identification of salt stress biomarkers in Romanian Carpathian populations of Picea abies(L.) Karst. PloSOne 10(8):e0135419.

Schütt P (1991). Abies alba. In:Tannenarten Europas und Kleinasiens. Birkhäuser, Basel pp 13-37.

Shvidenko A, Barber CV, Persson R (2005). Forest and woodland systems. In: Hassan R, Scholes R, Ash N (Eds). Ecosystems and human wellbeing: Current state and trends, Vol 1. Washington, DC, USA: Island Press pp 587-621.

Şofletea N, Curtu L (2007). Dendrologie. Editura Universităţii Transilvania, Braşov.

Stănescu V (1979). Dendrologie. Editura Didactică şi Pedagogică, București.

Sturrock RN, Frankel SJ, Brown AV, Hennon PE, Kliejunas JT, Lewis JJ, ... Woods AJ (2011). Climate change and forest diseases. Plant Pathology 60(1):133-149.

TinnerW, ColombaroliD, HeiriO, Henne PD, Steinacher M, Untenecker J, ... Valsecchi V (2013). The past ecology of Abies alba provides new perspectives on future responses of silver fir forests to global warming. Ecological Monographs 83(4):419-439.

WolfH (2003). EUFORGEN technical guidelines for genetic conservation and use for silver fir (Abies alba). International Plant Genetic Resources Institute, Rome, Italy.

Yadav S, Irfan M, Ahmad A, Hayat S (2011). Causes of salinity and plant manifestations to salt stress: a review. Journal of Environmental Biology 32(5):667-685.

ZhuJK(2001). Plant salt tolerance. Trends in Plant Science 6(2):66-71. 